\title{
IDENTIFIKASI PROTEASE UTAMA (Mpro) SEBAGAI MAKROMOLEKUL TARGET INHIBITOR NOVEL CORONAVIRUS 2019 (SARS-CoV-2) SECARA IN SILICO
}

\author{
Taufik Muhammad Fakih*, Mentari Luthfika Dewi \\ Program Studi Farmasi, Fakultas Matematika dan Ilmu Pengetahuan Alam, Universitas Islam Bandung, \\ J1. Rangga Gading No. 8, Bandung 40116, Indonesia \\ *email: taufikmuhammadf@gmail.com
}

\begin{abstract}
ABSTRAK
Protease utama (Mpro) merupakan bagian utama pembentuk karakteristik coronavirus (SARSCoV dan SARS-CoV-2). Kemajuan teknologi telah membuka peluang untuk menemukan kandidat molekul inhibitor baru yang mampu mencegah dan mengendalikan infeksi COVID19 melalui penghambatan Mpro SARS-CoV-2. Penelitian ini bertujuan untuk mengidentifikasi, mengevaluasi, dan mengeksplorasi struktur makromolekul Mpro dari kedua coronavirus tersebut secara in silico. Makromolekul Mpro terlebih dahulu dilakukan preparasi dengan menggunakan perangkat lunak BIOVIA Discovery Studio 2020. Konformasi tiga dimensi dan sekuensing dari struktur makromolekul Mpro yang telah dipreparasi kemudian diamati dan dibandingkan dengan menggunakan perangkat lunak Chimera 1.14 dan Notepad ++. Bagian sisi aktif dari makromolekul Mpro kemudian diidentifikasi dengan menggunakan perangkat lunak BIOVIA Discovery Studio 2020. Prediksi molekul inhibitor makromolekul Mpro dilakukan dengan menggunakan perangkat lunak MGLTools 1.5.6 yang dilengkapi dengan AutoDock 4.2. Berdasarkan hasil identifikasi terhadap makromolekul Mpro diperoleh hasil bahwa terdapat kemiripan struktur dan situs aktif pengikatan dari kedua makromolekul Mpro tersebut. Diprediksi bentuk molekul inhibitor dari kedua makromolekul Mpro juga identik. Dengan demikian, beberapa referensi tersebut dapat digunakan sebagai acuan dalam pengembangan kandidat inhibitor kompetitif Mpro SARS-CoV-2 untuk pengobatan penyakit infeksi COVID-19.
\end{abstract}

Kata kunci: Protease utama (Mpro), SARS-CoV, SARS-CoV-2, COVID-19, in silico.

\begin{abstract}
The main protease (Mpro) is the main part of forming coronavirus characteristics (SARS-CoV and SARS-CoV-2). Technological advances have opened up opportunities to find candidates for novel inhibitor molecules that can prevent and control COVID-19 infection through inhibition of SARS-CoV-2 Mpro. This research aims to identify, evaluate, and explore the Mpro macromolecular structure of the two coronaviruses through in silico. Mpro macromolecules were prepared using the BIOVIA Discovery Studio 2020 software. Three-dimensional conformation and sequencing of the prepared Mpro macromolecular structures were then observed and compared using Chimera 1.14 and Notepad ++ software. The active site of Mpro macromolecule was then identified using the BIOVIA Discovery Studio 2020 software. Prediction of the Mpro macromolecular inhibitor molecule was performed using MGLTools 1.5.6 with AutoDock 4.2 software. Based on the results of Mpro macromolecules identification, it was found that there are similarities in the structure and active binding sites of two Mpro macromolecules. The predicted shape of the inhibitor molecules of two Mpro macromolecules was also identical. Therefore, some of this information can be used as a reference in the development of competitive Mpro SARS-CoV-2 inhibitor candidates for the treatment of COVID-19 infectious diseases.
\end{abstract}

Keywords: Main protease (Mpro), SARS-CoV, SARS-CoV-2, COVID-19, in silico. 


\section{PENDAHULUAN}

Infeksi coronavirus 2019 (COVID-

19) yang pertama kali ditemukan di Kota Wuhan, Cina, saat ini telah menjadi penyakit pandemik karena penyebarannya telah sampai ke 25 negara di dunia (Wang dkk., 2020). Karena kejadian tersebut, Organisasi Kesehatan Dunia (WHO) mengumumkan darurat kesehatan global pada tanggal 30 Januari 2020 (Huang dkk., 2020; Heymann, 2020). WHO dalam pertemuan pertamanya memperkirakan tingkat kematian COVID-19 mencapai sekitar 4\% (Liu dan Wang, 2020). Upaya para peneliti untuk memahami karakteristik dari SARS-CoV-2 (awalnya bernama 2019$\mathrm{nCoV}$ ) dapat digunakan sebagai langkah awal dalam pengendalian dan pencegahan COVID-19 (Zhou dkk., 2020).

Protease utama (Mpro) merupakan salah satu komponen penting yang terdapat dalam coronavirus. Fungsi utama dari Mpro yaitu melepaskan polipeptida fungsional dari poliprotein melalui proses proteolitik (Jin dkk., 2020). Terdapat dua poliprotein yang diperlukan untuk replikasi dan transkripsi coronavirus, antara lain ppla dan pplb (Lu dkk., 2020). Poliprotein ini dikode oleh genom dari coronavirus yang terdiri dari kurang lebih 30.000 nukleotida. Selain itu, Mpro juga digunakan oleh coronavirus (SARS-CoV dan SARS CoV2) untuk berinteraksi secara langsung dengan Angiotensin-Converting Enzyme 2
(ACE-2) sehingga dapat masuk ke dalam sel target (Walls dkk., 2020).

Studi pendahuluan menunjukkan bahwa karakteristik dari SARS-CoV-2 identik dengan SARS-CoV berdasarkan analisis filogenetik genom secara lengkap (Letko dan Munster, 2020; Hoffmann dkk., 2020). Dengan demikian, dapat diprediksi struktur Mpro pada SARS-CoV dan SARSCoV memiliki kemiripan. Dalam penelitian akan dilakukan studi lebih lanjut untuk mengidentifikasi, mengevaluasi, dan mengeksplorasi struktur makromolekul dari kedua coronavirus ini secara in silico. Melalui penelitian ini diharapkan didapatkan beberapa referensi untuk pengembangan kandidat molekul inhibitor SARS-CoV-2 Mpro.

\section{METODE PENELITIAN}

\subsection{Alat dan Bahan}

Bahan yang digunakan dalam penelitian ini adalah struktur kristal makromolekul protease utama (Mpro) dari SARS-CoV dan SARS-CoV-2. Makromolekul Mpro tersebut diperoleh dari web Protein Data Bank (http://www.rcsb.org/pdb) dengan kode PDB 1UK4 (Yang dkk., 2003) dan 6LU7 (Jin dkk., 2020). Perangkat lunak yang digunakan dalam penelitian ini adalah Sistem Operasi Windows 10, MGLTools 1.5.6 yang dilengkapi dengan AutoDock 4.2, Chimera 1.14, BIOVIA Discovery Studio 2020, dan Notepad ++. Perangkat 
Identifikasi Protease Utama (Mpro) Sebagai Makromolekul...

keras yang digunakan dalam penelitian ini adalah komputer dengan spesifikasi processor Intel (R) Core i3-6100 CPU @ $2.30 \mathrm{GHz}$ (4 CPUs), memory $4096 \mathrm{MB}$ RAM, Harddisk 320GB, dan VGA Intel HD Graphics 520.

\subsection{Preparasi Struktur Makromolekul Protease Utama (Mpro)}

Struktur makromolekul protease utama (Mpro) dari SARS-CoV dan SARSCoV-2 yang telah diunduh dari web Protein Data Bank kemudian dilakukan preparasi terlebih dahulu. Preparasi struktur makromolekul dilakukan dengan menghilangkan molekul air dan ligan alami (Kurniawan dkk., 2018). Preparasi ini dilakukan dengan menggunakan perangkat lunak BIOVIA Discovery Studio 2020.

\subsection{Analisis Konformasi Tiga Dimensi} Struktur Makromolekul Protease Utama (Mpro)

Makromolekul protease utama (Mpro) yang telah dipreparasi kemudian dilakukan tumpang tindih struktur makromolekul. Analisis ini bertujuan untuk mengidentifikasi kemiripan dan mengamati adanya perbedaan dari struktur makromolekul Mpro SARS-CoV dan Mpro SARS-CoV-2 (Meng dkk., 2006). Tahapan ini dilakukan dengan menggunakan perangkat lunak Chimera 1.14 dan BIOVIA Discovery Studio 2020.

\subsection{Identifikasi Sekuensing Struktur Makromolekul Protease Utama (Mpro)}

Pengamatan lebih lanjut dilakukan identifikasi terhadap sekuensing dari makromolekul protease utama (Mpro) SARS-CoV dan SARS-CoV-2. Residu asam amino yang berperan sebagai penyusun struktur makromolekul Mpro kemudian dievaluasi dan dieksplorasi (da Costa dkk., 2019). Identifikasi ini dilakukan dengan menggunakan perangkat lunak BIOVIA Discovery Studio 2020 dan Notepad ++.

\subsection{Evaluasi Sisi Aktif Struktur Makromolekul Protease Utama (Mpro)}

Struktur makromolekul protease utama (Mpro) kemudian diidentifikasi bagian situs pengikatan yang paling bertanggung jawab terhadap aktivitas biologis (Kemmish, Fasnacht, dan Yan, 2017). Ligan alami dari kedua makromolekul Mpro SARS-CoV dan Mpro SARS-CoV-2 digunakan untuk memprediksi sisi aktif dari struktur makromolekul tersebut. Evaluasi ini dilakukan menggunakan perangkat lunak BIOVIA Discovery Studio 2020.

\subsection{Prediksi Inhibitor Makromolekul Protease Utama (Mpro)}

Melalui beberapa referensi pada tahapan sebelumnya, selanjutnya dilakukan prediksi molekul yang mampu 
menghambat makromolekul target dari Mpro SARS-CoV dan Mpro SARS-CoV-2. Prediksi struktur molekul inhibitor ini dilakukan dengan menggunakan perangkat lunak MGLTools 1.5.6 yang dilengkapi dengan AutoDock 4.2. Hasil yang diperoleh adalah nilai energi bebas ikatan dan konstanta inhibisi (Forli dkk., 2016).

\section{HASIL DAN PEMBAHASAN}

Dalam penelitian ini dilakukan identifikasi, evaluasi, dan eksplorasi terhadap makromolekul protease utama
(Mpro) dari SARS-CoV dan SARS-CoV-2 untuk mengamati karakteristik struktur penyusunnya secara in silico. Terlebih dahulu dilakukan preparasi makromolekul Mpro dengan menghilangkan molekul air dan ligan alami dengan menggunakan perangkat lunak BIOVIA Discovery Studio 2020. Preparasi makromolekul ini dilakukan dengan tujuan untuk memudahkan pengamatan pada tahapan identifikasi selanjutnya.

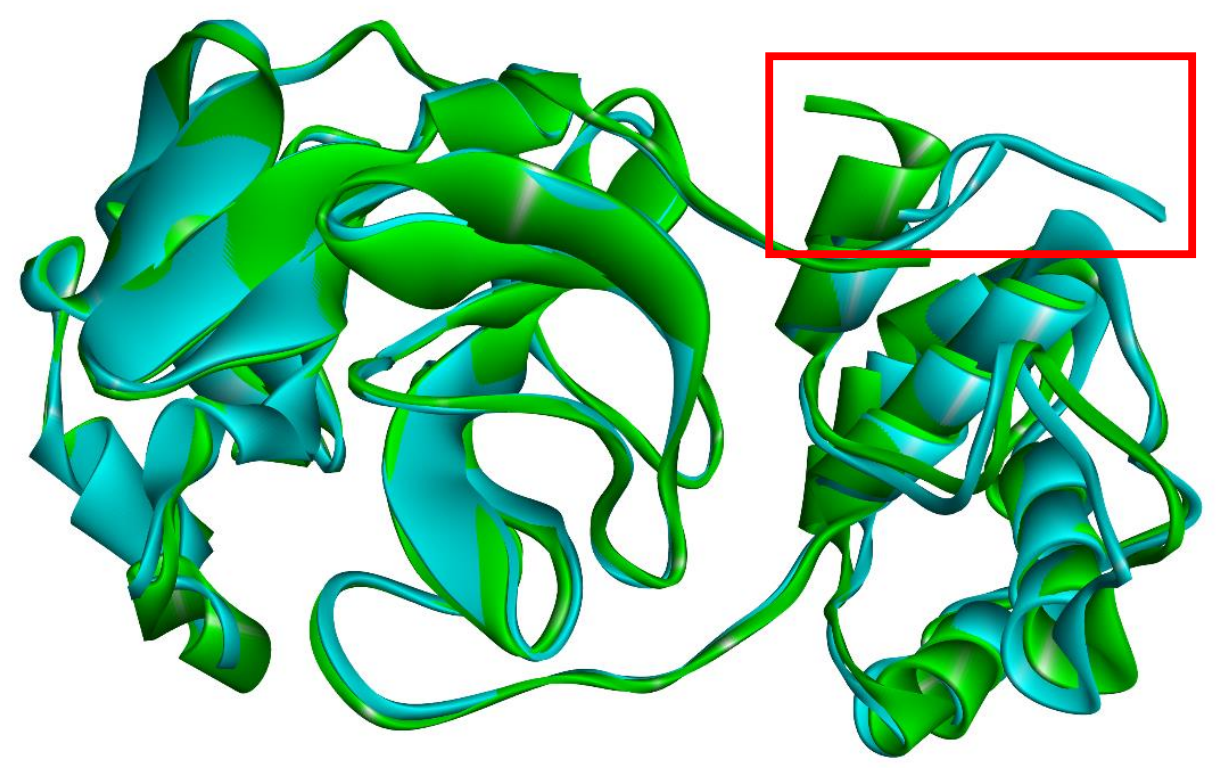

Gambar 1. Struktur Makromolekul Mpro SARS-CoV (hijau) dan Mpro SARS-CoV-2 (biru) dalam Keadaan Tumpang Tindih.

Representasi kedua makromolekul Mpro dibuat dalam bentuk struktur sekunder sehingga dapat diamati bagian alpha helix, beta sheet, dan loop. Sebagaimana yang ditunjukkan oleh Gambar 1, secara keseluruhan makromolekul Mpro SARS-CoV dan Mpro SARS-CoV-2 memiliki kemiripan yang signifikan. Namun, terdapat sedikit perbedaan pada bagian ujung dari makromolekul tersebut (kotak berwarna merah). Bagian ujung dari makromolekul Mpro SARS-CoV berbentuk alpha helix, sementara pada Mpro SARS-CoV-2 justru membentuk loop. Hal tersebut membuktikan bahwa terdapat beberapa perbedaan residu asam amino penyusun dari kedua makromolekul Mpro. 
FRKMAFPSGKVEGCMVQVTCGTTTLNGLWLDDTVYCPRHVICTAEDMLNPNYEDLLI RKSNHSFLVQAGNVQLRVIGHSMQNCLLRLKVDTSNPKTPKYKFVRIQPGQTFSVLAC YNGSPSGVYQCAMRPNHTIKGSFLNGSCGSVGFNIDYDCVSFCYMHHMELPTGVHAG TDLEGKFYGPFVDRQTAQAAGTDTTITLNVLAWLYAAVINGDRWFLNRFTTTLNDF NLVAMKYNYEPLTQDHVDILGPLSAQTGIAVLDMCAALKELLQNGMNGRTILGSTILE DEFTPFDVVRQCSGV

SGFRKMAFPSGKVEGCMVQVTCGTTTLNGLWLDDVVYCPRHVICTSEDMLNPNYEDL LIRKSNHNFLVQAGNVQLRVIGHSMQNCVLKLKVDTANPKTPKYKFVRIQPGQTFSVL ACYNGSPSGVYQCAMRPNFTIKGSFLNGSCGSVGFNIDYDCVSFCYMHHMELPTGVHA GTDLEGNFYGPFVDRQTAQAAGTDTTITVNVLAWLYAAVINGDRWFLNRFTTTLND FNLVAMKYNYEPLTQDHVDILGPLSAQTGIAVLDMCASLKELLQNGMNGRTILGSALL EDEFTPFDVVRQCSGVTFQ

Gambar 2. Sekuensing dari Struktur Makromolekul Mpro SARS-CoV (hijau) dan Mpro SARS-CoV-2 (biru).

Pengamatan lebih lanjut dilakukan terhadap sekuensing dari masing-masing makromolekul Mpro. Hampir sebagian besar terdapat kesamaan residu asam amino antara SARS-CoV dan SARS-CoV-2 (Gambar 2). Akan tetapi, terlihat perbedaan yang sangat jelas yaitu 5 residu asam amino (Ser1, Gly2, Thr304, Phe305, danGln306) yang terletak pada bagian ujung dari struktur makromolekul Mpro dari SARS-
CoV-2. Kemudian, di bagian tengah struktur makromolekul terdapat 12 residu asam amino yang berbeda, antara lain Val35, Ser46, Asn65, Val86, Lys88, Ala94, Phe134, Asn180, Val202, Ser267, Ala285, dan Leu286. Selain itu, makromolekul Mpro SARS-CoV-2 juga memiliki jumlah residu asam amino yang lebih banyak yaitu 306, sementara Mpro SARS-CoV hanya 303.

Tabel 1. Sisi Aktif Makromolekul Mpro SARS-CoV dan Mpro SARS-CoV-2.

\begin{tabular}{cc}
\hline Mpro SARS-CoV & Mpro SARS-CoV-2 \\
\hline His41, Phe140, Gly143, & His41, Met49, Phe140, Leu141, Asn142, Gly143, His163, His164, \\
Ser144, Glu166 & Met165, Glu166, Pro168, His172, Gln189, Thr190, Ala191 \\
\hline
\end{tabular}

Seperti yang ditunjukkan pada Tabel 1, bagian sisi aktif dari makromolekul Mpro SARS-CoV-2 cenderung lebih banyak dari Mpro SARS-CoV, yaitu dengan 15 residu asam amino. Apabila kedua situs aktif pengikatan makromolekul dibandingkan, terdapat beberapa residu asam amino yang memiliki kesamaan, antara lain His41, Phe140, Gly143, dan Glu166. Fenomena ini menunjukkan bahwa 
dapat diprediksi struktur molekul inhibitor dari Mpro SARS-CoV dan Mpro SARSCoV-2 tidak akan jauh berbeda. Sebagian besar inhibitor bekerja dengan mengikat kuat ke situs aktif pengikatan makromolekul target dan bersaing dengan ligan alaminya, serta menstabilkan struktur makromolekul dan mencegah perubahan konformasi yang diperlukan untuk makromolekul dalam mengkatalisasi reaksi.

Tabel 2. Afinitas Ligan Alami terhadap Makromolekul Mpro SARS-CoV dan Mpro SARSCoV-2.

\begin{tabular}{ccc}
\hline Makromolekul Mpro & Energi Bebas Ikatan & Konstanta Inhibisi \\
\hline SARS-CoV & $-16,82 \mathrm{~kJ} / \mathrm{mol}$ & $1,12 \mathrm{mM}$ (milimolar) \\
SARS-CoV-2 & $-18,58 \mathrm{~kJ} / \mathrm{mol}$ & $553,91 \mathrm{uM}$ (mikromolar) \\
\hline
\end{tabular}

Tahapan pengamatan terhadap afinitas ligan alami makromolekul Mpro dilakukan untuk memprediksi struktur molekul inhibitor dari Mpro SARS-CoV-2. Tabel 2 menunjukkan bahwa ligan alami pada Mpro SARS-CoV-2 mengikat kuat pada bagian sisi aktif dari makromolekul. Nilai energi bebas ikatan dari ligan alami yang terikat pada makromolekul Mpro SARS-CoV juga tidak menunjukkan perbedaan yang signifikan. Oleh karena itu, dapat diprediksi bahwa molekul inhibitor dari kedua makromolekul Mpro memiliki kemiripan. Tahapan pemodelan struktur molekul acuan untuk menghambat Mpro SARS-CoV-2 dapat menggunakan referensi dari residu asam amino yang bertanggung terhadap aktivitasnya dan ligan alami yang terikat kuat pada bagian sisi aktif makromolekul.

\section{KESIMPULAN}

Berdasarkan penelitian yang telah dilakukan, diperoleh hasil bahwa terdapat beberapa kemiripan antara struktur makromolekul protease utama (Mpro) dari SARS-CoV dan SARS-CoV-2. Struktur molekul acuan untuk pemodelan inhibitor kompetitif dapat dibuat dengan cara mempelajari residu asam amino yang berperan pada situs aktif pengikatan makromolekul Mpro SARS-CoV-2 dan juga dengan menggunakan struktur ligan alami yang telah membentuk kompleks. Dengan demikian, beberapa referensi yang diperoleh dari penelitian ini dapat digunakan sebagai upaya dalam pengembangan molekul inhibitor yang mampu mencegah dan mengendalikan penyakit infeksi COVID-19.

\section{UCAPAN TERIMA KASIH}

Penulis mengucapkan terima kasih kepada LPPM (Lembaga Penelitian dan Pengabdian kepada Masyarakat), Universitas Islam Bandung, atas dukungan finansial yang diberikan melalui skema 
Identifikasi Protease Utama (Mpro) Sebagai Makromolekul...

hibah Penelitian Khusus tahun 2020, No.039/B.04/LPPM/IV/2020.

\section{DAFTAR PUSTAKA}

Da Costa KS, Galucio JM, Da Costa CHS, Santana AR, Carvalho VDS, dan Do Nascimento LD., 2019. Exploring the Potentiality of Natural Products from Essential Oils as Inhibitors of Odorant-Binding Proteins: A Structure- and Ligand-Based Virtual Screening Approach To Find Novel Mosquito Repellents, ACS Omega, 4(27): 22475 - 22486.

Forli S, Huey R, Pique ME, Sanner M, Goodsell DS, dan Olson AJ., 2016. Computational protein-ligand docking and virtual drug screening with the AutoDock suite, Nature Protocols, 11(5):905 - 919.

Heymann DL., 2020. Data sharing and outbreaks: Best practice exemplified, Lancet, 395(10223):469 - 470.

Hoffmann M, Kleine-Weber H, Kruger N, Muller M, Drosten C, dan Pohlmann S., 2020. The novel coronavirus 2019 (2019-nCoV) uses the SARScoronavirus receptor ACE2 and the cellular protease TMPRSS2 for entry into target cells.

Huang C, Wang Y, Li X, Ren L, Zhao J, Hu Y, Zhang L, Fan G, Xu J, Gu X, Cheng Z, Yu T, Xia J, Wei Y, Wu W, Xie X, Yin W, Li H, Liu M, Xiao Y, Gao H, Guo L, Xie J, Wang G, Jiang R, Gao Z, Jin Q, Wang J, dan Cao B., 2020. Clinical features of patients infected with 2019 novel coronavirus in Wuhan, China, Lancet, 395(10223):497 - 506.

Jin Z, Du X, Xu Y, Deng Y, Liu M, Zhao Y, Zhang B, Li X, Zhang L, Peng C, Duan Y, Yu J, Wang L, Yang K, Liu F, Jiang R, Yang X, You T, Liu X, Yang X, Bai F, Liu H, Liu X, Guddat LW, Xu W, Xiao G, Qin C, Shi Z, Jiang H, Rao Z, dan Yang H., 2020. Structure of Mpro from COVID-19 virus and discovery of its inhibitors.
Kemmish H, Fasnacht M, dan Yan L., 2017. Fully automated antibody structure prediction using BIOVIA tools: Validation study. PLoS One, 12(5): 0177923.

Kurniawan F, Miura Y, Kartasasmita RE, Yoshioka N, Mutalib A, dan Tjahjono DH., 2018. In silico study, synthesis, and cytotoxic activities of porphyrin derivatives, Pharmaceuticals, 11(1):8.

Letko M, dan Munster V., 2020. Functional assessment of cell entry and receptor usage for lineage $\mathrm{B} \beta$-coronaviruses, including 2019-nCoV. Nature Microbiology, 5:562 - 569.

Liu X, dan Wang XJ., 2020. Potential inhibitors for 2019-nCoV coronavirus $\mathrm{M}$ protease from clinically approved medicines, Journal of Genetics and Genomics, 47(2):119 - 121.

Lu R, Zhao X, Li J, Niu P, Yang B, Wu H, Wang W, Song H, Huang B, Zhu N, Bi Y, Ma X, Zhan F, Wang L, Hu T, Zhou H, Hu Z, Zhou W, Zhao L, Chen J, Meng Y, Wang J, Lin Y, Yuan J, Xie Z, Ma J, Liu WJ, Wang D, Xu W, Holmes EC, Gao GF, Wu G, Chen W, Shi W, dan Tan W., 2020. Genomic characterisation and epidemiology of 2019 novel coronavirus: Implications for virus origins and receptor binding. Lancet, 395(10224):565 - 574.

Meng EC, Pettersen EF, Couch GS, Huang CC, dan Ferrin TE., 2006. Tools for Integrated Sequence-Structure Analysis With UCSF Chimera, BMC Bioinformatics, 7:339.

Walls AC, Park YJ, Tortorici MA, Wall A, McGuire AT, dan Veesler D., 2020. Structure, Function, and Antigenicity of the SARS-CoV-2 Spike Glycoprotein. Cell, 180:1 - 12 .

Wang C, Horby PW, Hayden FG, dan Gao GF., 2020. A novel coronavirus outbreak of global health concern, Lancet, 395(10223):470 - 473.

Yang H, Yang M, Ding Y, Liu Y, Lou Z, Zhou Z, Sun L, Mo L, Ye S, Pang H, Gao GF, Anand K, Bartlam M, 
Hilgenfeld R, dan Rao Z., 2003. The crystal structures of severe acute respiratory syndrome virus main protease and its complex with an inhibitor, Proceedings of the National Academy of Sciences of the United States of America, 100(23):13190 13195

Zhou P, Yang XL, Wang XG, Hu B, Zhang

L, Zhang W, Si HR, Zhu Y, Li B,
Huang CL, Chen HD, Chen J, Luo Y, Guo H, Jiang RD, Liu MQ, Chen Y, Shen XR, Wang X, Zheng XS, Zhao K, Chen QJ, Deng F, Liu LL, Yan B, Zhan FX, Wang YY, Xiao GF, dan Shi ZL., 2020. A pneumonia outbreak associated with a new coronavirus of probable bat origin. Nature, 579(7798): 270 - 273. 